https://nv.nltu.edu.ua

https://doi.org/10.15421/40290221

Article received 20.02.2019 p.

Article accepted 28.03.2019 p.

I. V. Petryshak

удк 674.048

borason@ukr.net

Ю. М. Губер, І. В. Петришак, Ж. Я. Гуменюк, М. М. Ільків

Національний лісотехнічний університет Украӥни, м. Львів, Украӥна

\title{
ДОСЛІДЖЕННЯ ПРОЦЕСУ ГНУТТЯ ДЕРЕВИНИ БУКА У ПРЕСІ З ВИСОКОЧАСТОТНИМ НАГРІВАННЯМ
}

\begin{abstract}
Перспективною технологією виготовлення гнутих деталей із масивної деревини $є$ використання пресів, обладнаних генераторами СВЧ. Нагрівання деревини в полі струмів високої частоти дає змогу швидко нагріти її до потрібної температури, за якої пластичні властивості деревини будуть найкращими. Час на повний цикл гнуття становить $20 \ldots 40$ хв, тиск - до $500 \mathrm{\kappa r} / \mathrm{cm}^{2}$, кінцева вологість заготовок $-6 \ldots 8 \%$. Ця технологія істотно зменшує час на гнуття та підвищує продуктивність порівняно з іншим обладнанням та технологіями. Наведено методику та результати дослідження процесу гнуття деревини бука у пресах з високочастотним нагріванням, а також вплив технологічних параметрів безпосередньо на якість оброблених заготовок. Дослідження проведено в умовах виробництва із застосуванням преса італійської фірми Italpresse, загальною потужністю 35 кВт. Експерименти проведено на шаблоні для гнуття із стрілою прогину 70 мм з використанням заготовок завдовжки 975 мм та поперечним перерізом $37 \times 27$ мм. Аналізуючи якість гнуття, визначено кількість придатних заготовок. Неякісною вважали заготовку, придатність якої $є$ неможливою через наявність у ній тріщин, сколів, вм'ятин, потемніння та інших дефектів, що унеможливлює їі використання з естетичних чи фізико-механічних вимог у виробництві меблевих виробів. За результатами досліджень отримано три групи графіків залежності частки виходу якісних заготовок від часу витримки, напруженості електромагнітного поля та тиску пресування. На основі аналізу отриманих графічних залежностей зроблено такі висновки: 1) збільшення тиску пресування до межі 100 кг $\mathrm{cm}^{2}$ призводить до зменшення частки якісних заготовок, а

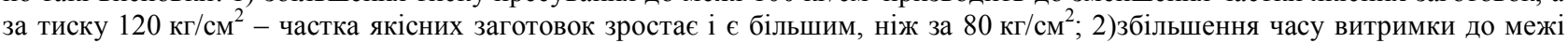
20 хв призводить до зростання частки якісних заготовок, а за межі 30 хв - до зменшення частки якісних заготовок; 3) із зростанням напруженості електромагнітного поля частка якісних заготовок зменшується. Для знаходження оптимальних параметрів процесу гнуття букових заготовок виконано оптимізацію, за результатами якої можна стверджувати, що найбільшу кількість якісних гнутих заготовок $(98,63$ \%) можна отримати за найменшої напруженості електромагнітного поля та за найбільшого значення тиску пресування, і витримки заготовок під тиском упродовж 20 хв 40 с.
\end{abstract}

Ключові слова: заготовки бука; процес гнуття; час витримки; напруженість електромагнітного поля; тиск пресування.

Вступ. Однією з перспективних технологій отримання гнутих деталей $є$ гнуття деревини $з$ одночасним iii нагріванням у полі струмів високої частоти (СВЧ) (Goncharov, Bashinskikh \& Buglai, 1990). Нагрівання деревини в полі СВЧ дає змогу швидко ії нагріти до потрібної температури для впливу на іiі пластичні властивості. Процес гнуття деревини дає змогу економити матеріал під час виготовлення деталей криволінійної форми, а іï гнуття з одночасним нагріванням у полі струмів високої частоти дає ще й можливість економити час, який потрібний на виготовлення гнутої деталі.

Мета досліджень - експериментально дослідити процес гнуття деревини бука у пресах з високочастотним нагріванням, а також вплив технологічних параметрів на процес гнуття для отримання оптимальних значень параметрів процесу пресування.
Матеріали та методика дослідження. Дослідження проводили в умовах виробництва із застосуванням преca італійської фірми Italpresse загальною потужністю 35 кВт. Для виконання цієї технологічної операції застосовують близько 15 видів прес-форм (для восьми типорозмірів задніх ніжок стільців), на кожну з яких встановлюють від 24 до 30 заготовок вологістю $18 \%$. Час повного циклу гнуття становить $20 \ldots 40$ хв, тиск - до $500 \mathrm{\kappa г} / \mathrm{cm}^{2}$, кінцева вологість заготовок $-6 . .8 \%$. Технологія істотно зменшує час гнуття та підвищує продуктивність порівняно з іншим обладнанням та технологіями. Установку для гнуття заготовок деревини в полі СВЧ зображено на рис. 1.

Заготовки деревини із початковою вологістю, меншою за 17 \% попередньо пластифікують. Процес пластифікації заготовок проводять шляхом їх пропарювання

\section{Інформація про авторів:}

Губер Юрій Мирославович, канд. техн. наук, доцент, кафедра технологій захисту навколишнього середовища, деревини, безпеки життєдіяльності та соціальних комунікацій. Email: tszd@nltu.edu.ua

Петришак Ігор Васильович, канд. техн. наук, доцент, кафедра технологій захисту навколишнього середовища, деревини, безпеки життєдіяльності та соціальних комунікацій. Email: borason@ukr.net

Гуменюк Жанна Ярославівна, асистент, кафедра технологій захисту навколишнього середовища, деревини, безпеки житєєіяльності та соціальних комунікацій. Email: zhanna.humenyuk@nltu.edu.ua

Ільків Михайло Миколайович, асистент, кафедра технологій меблів та виробів з деревини. Email: mykhailo.ilkiv@nltu.edu.ua

Цитування за ДСтУ: Губер Ю. М., Петришак І. В., Гуменюк Ж. Я., Ільків М. М. Дослідження процесу гнуття деревини бука у пресі 3 високочастотним нагріванням. Науковий вісник НлтУ України. 2019, т. 29, № 2. С. 103-108.

Citation APA: Huber, Yu. M., Petryshak, I. V., Humeniuk, Zh. Ya., \& Ilkiv, M. M. (2019). Studying the process of beech wood bending in the high frequency hot press machine. Scientific Bulletin of UNFU, 29(2), 103-108. https://doi.org/10.15421/40290221 
у пропарювальних барабанах за тиску пари $0,02 \ldots 0,05$ МПа і температури $102 \ldots 105{ }^{\circ} \mathrm{C}$ до оптимальної вологості $18 \ldots 20 \%$. Пропарювальні барабани мають ді-

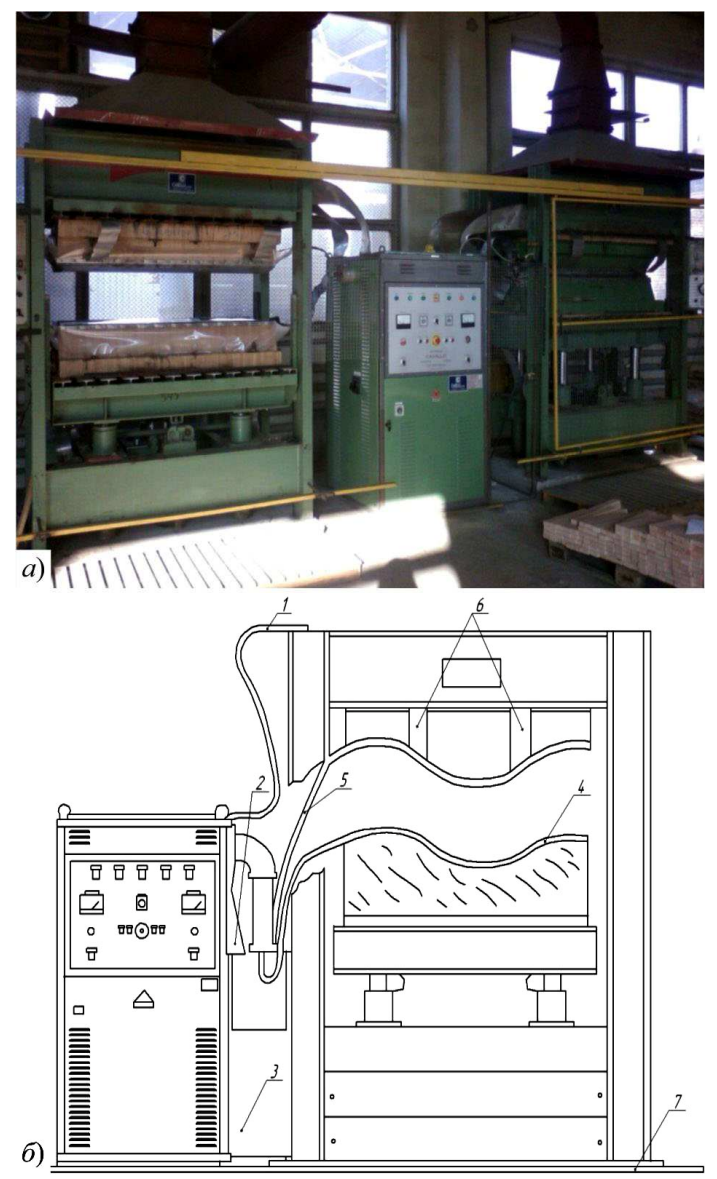

Рис. 1. Прес для гнуття заготовок деревини в полі струмів високої частоти: 1) заземлювач; 2) захисна решітка пресу; 3) решітка; 4) матриця ("+"); 5) з'єднувальна смуга ("-"); 6) заземлювальні пластини матриці ("-")

Тривалість процесу пропарювання заготовок залежить від розмірів і вологості деревини. За вологості заготовок 7..10\% значний вплив на тривалість процесу пропарювання має порода деревини. За вологості деревини, близької до точки насичення волокон, потрібен час для пропарювання майже однаковий для всіх порід (Bilei, 2013).
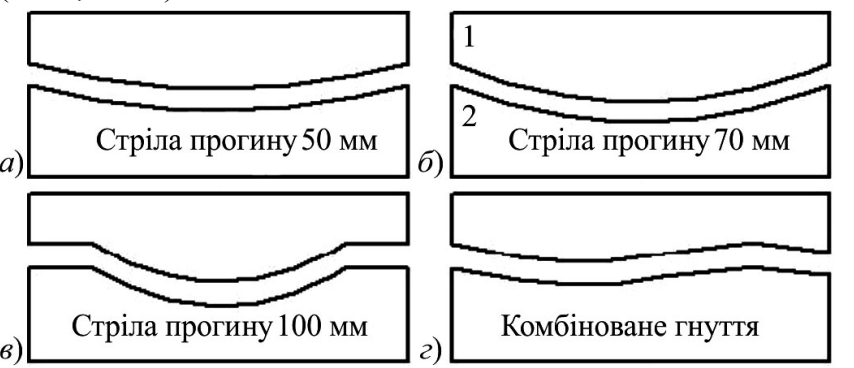

Рис. 3. Шаблони для гнуття деревини: 1) матриця; 2) пуансон

Потрібну форму заготовкам надають за допомогою шаблонів. Виготовляють шаблони 3 фанерних плит, склеюючи їх між собою з подальшим наданням їм певної форми, яка і визначатиме типовий радіус тої чи іншої моделі (рис. 3). Шаблони " $a$ ", " $\sigma$ " і "г" використовують для гнуття задніх ніжок стільців. Шаблон " 8 " використовують для гнуття спинки стільця.

Експерименти проведено на шаблоні типу "б" (див. рис. 3), стріла прогину якого дорівнює 70 мм і який аметр 0,3...0,4 м і обладнані контрольно-вимірювальною апаратурою (рис. 2).

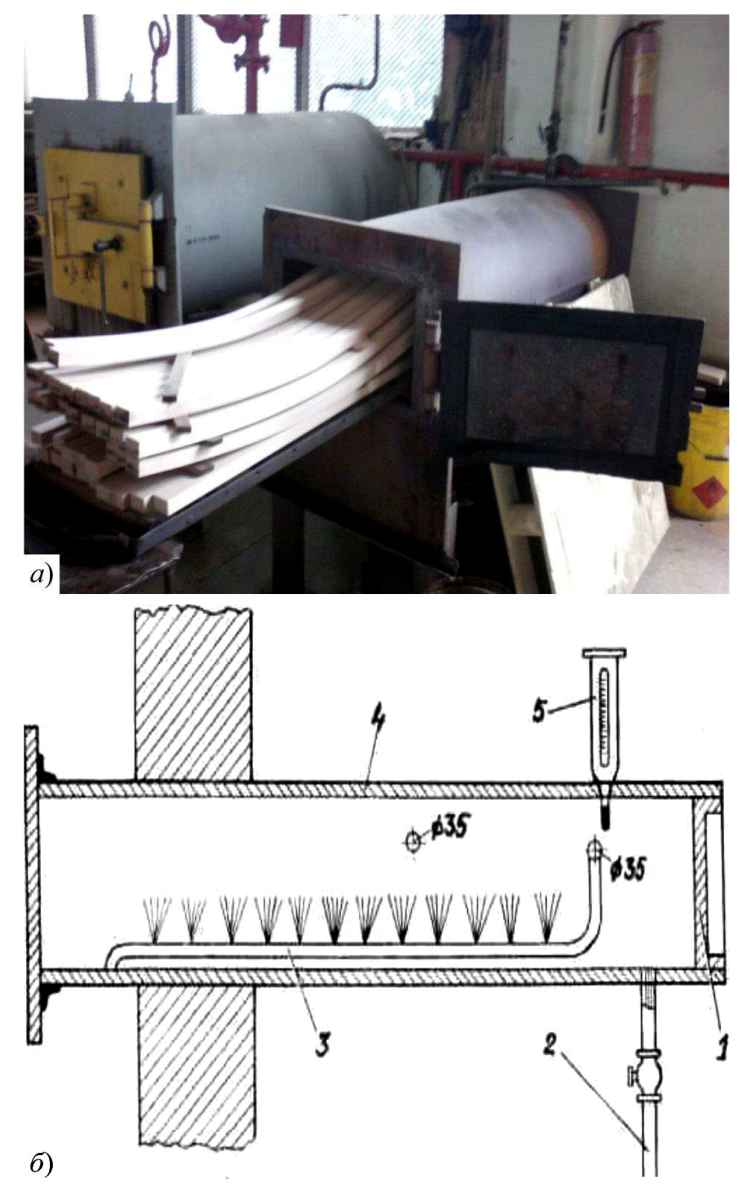

Рис. 2. Пропарювальний барабан: 1) кришка; 2) спускна труба; 3) парова труба; 4) циліндр; 5) термометр і манометр

призначений для гнуття задньої ніжки стільця моделі "Валерія".

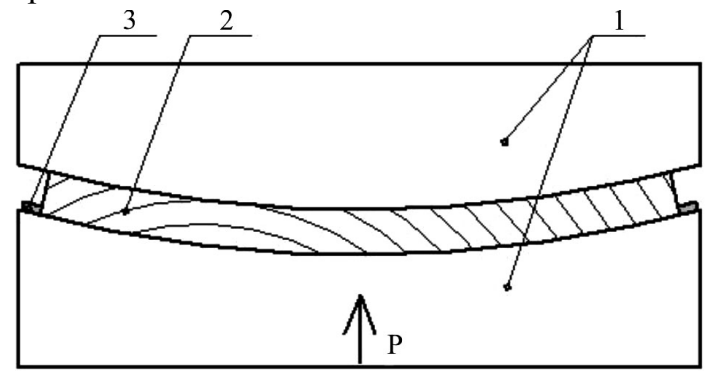

Рис. 4. Схема пресування заготовки: 1) плити преса; 2) заготовка; 3 ) касета для закріплення заготовок

Перед проведенням експериментальних досліджень якості гнуття заготовок деревини було визначено товщину заготовок. Оскільки їх товщина була меншою ніж 40 мм, то відповідно до ГОСТ 16588-79 (GOST 1658891, 2009), вологість вимірювали електровологоміром GANNHT-85T. Із партії заготовок у кількості 100 шт. вимірювання вологості проводили на 6 заготовках, після чого знаходили середнє значення вологості партії. Допустимою вологістю перед гнуттям вважають $18^{ \pm 1} \%$.

Перед початком пресування плити пресу розігрівали. Для цього використовують браковані деталі, які закріплюють у касеті плит преса і проводять попереднє їх нагрівання. Це дає змогу отримати меншу кількість 
браку у першій партії заготовок. Для досліджень використовували заготовки деревини бука розмірами $37 \times 27 \times 975$ мм. Максимальний вміст заготовок у касеті преса -30 шт.

Час витримки заготовок у пресі залежить від породи, їх товщини і вологості. Покази під час дослідження знімалися з пультів керування, де розміщені манометри тисків, амперметри, а також таймери часу пресування i витримки у пресі.

На основі проведеного аналізу обладнання і технологій гнуття прийнято такі значення постійних вхідних факторів: робоча частота генератора $f_{p}=3,3 \ldots 11,5 \mathrm{MГц,}$ анодний струм $I_{a}=2 \ldots 3 \mathrm{~A}$, катодний струм $I_{\kappa}=$ $0,2 \ldots 0,8$ А, стріла прогину $R=70$ мм, вологість дереви-
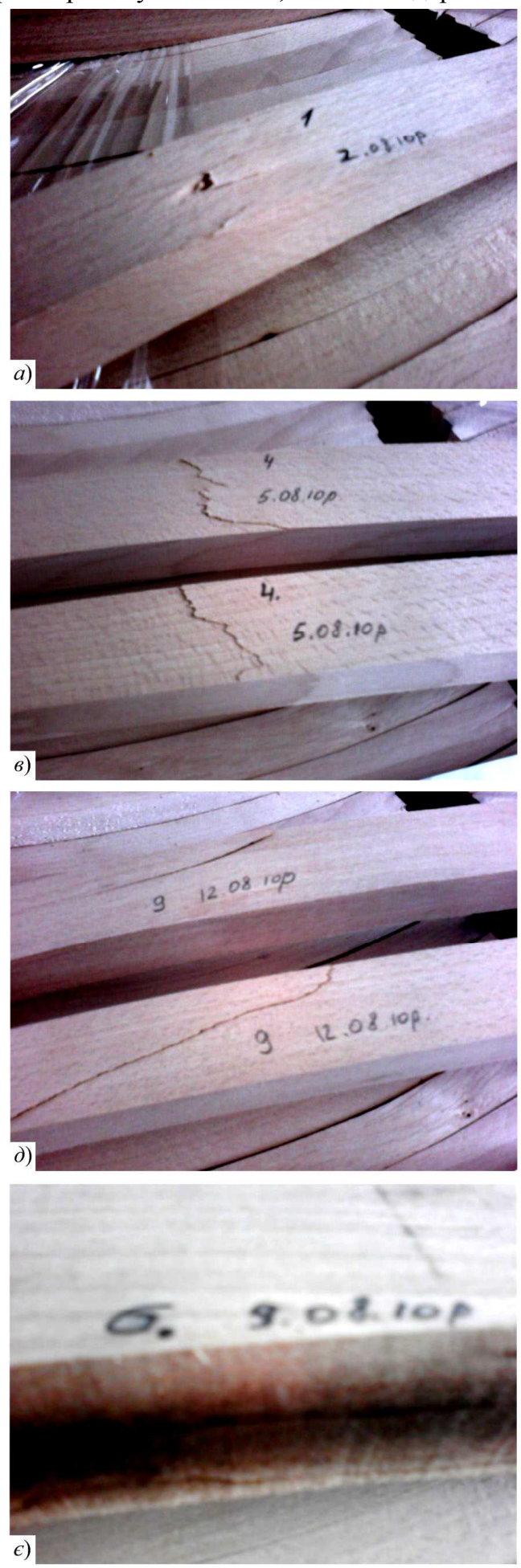

Рис. 5. Основні види браку, отриманого в процесі гнуття заготовок деревини ни до оброблення $W_{n}=18 \%$, порода деревини: бук $\left(\rho_{y м}\right.$ $\left.=670 \mathrm{\kappa г} / \mathrm{M}^{3}\right)$, місткість пресу $n=30$ шт.

Методичну сітку експериментальних досліджень частки якісних деталей, отриманих у процесі гнуття 3 одночасним нагріванням у полі струмів високої частоти, зведено у табл. 1.

У процесі аналізу якості процесу гнуття візуально визначали кількість якісних заготовок. Неякісною вважали заготовку, придатність якої є неможливою через наявність у ній тріщин, сколів, вм'ятин, потемніння та інших дефектів, які унеможливлюють використання іiї 3 естетичних чи фізико-механічних вимог у виготовленні меблевих виробів. Основні види браку показано на рис. 5.
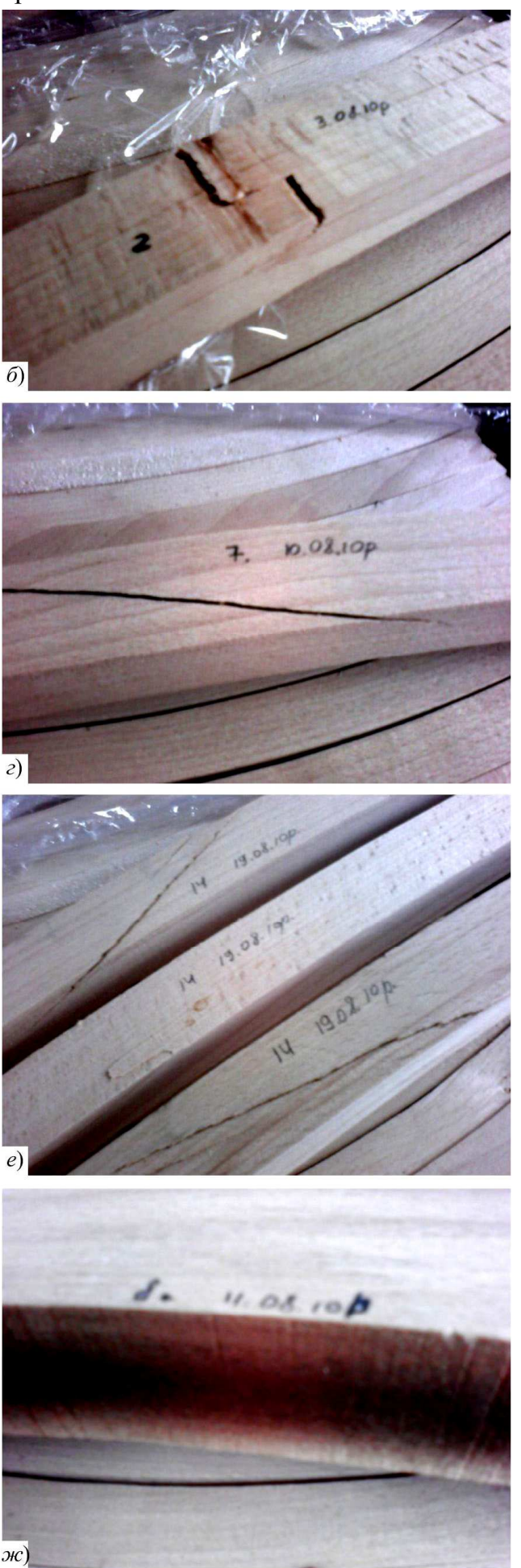
Табл. 1. Методична сітка дослідів експериментальних досліджень

\begin{tabular}{|c|c|c|c|c|c|c|c|c|c|c|c|}
\hline \multirow{3}{*}{ № 3/ח } & \multirow[b]{3}{*}{ Назва фактора } & \multirow{3}{*}{$\begin{array}{c}\text { Одиниця } \\
\text { вимірюван- } \\
\text { ня }\end{array}$} & \multirow{3}{*}{$\begin{array}{c}\text { Натуральне } \\
\text { позначення } \\
\text { фактора } X_{i}\end{array}$} & \multirow{3}{*}{$\begin{array}{c}\text { Кодоване } \\
\text { тозначення } \\
\text { фактора } x_{i}\end{array}$} & \multirow{3}{*}{\begin{tabular}{|c|} 
Інтервал \\
зміни \\
фактора \\
$\Delta x_{i}$
\end{tabular}} & \multicolumn{6}{|c|}{ Рівень фактора } \\
\hline & & & & & & \multicolumn{2}{|c|}{ нижній } & \multicolumn{2}{|c|}{ основний } & \multicolumn{2}{|c|}{ верхній } \\
\hline & & & & & & \begin{tabular}{|c|} 
натур. \\
значення
\end{tabular} & $\begin{array}{l}\text { код. зна- } \\
\text { чення }\end{array}$ & $\begin{array}{c}\text { натур. } \\
\text { значення }\end{array}$ & $\begin{array}{c}\text { код. зна- } \\
\text { чення }\end{array}$ & \begin{tabular}{|c|} 
натур. \\
значення
\end{tabular} & $\begin{array}{c}\text { код. зна- } \\
\text { чення }\end{array}$ \\
\hline 1 & Тиск пресування & $\mathrm{\kappa} / \mathrm{cm}^{2}$ & $\bar{P}$ & $x_{1}$ & 20 & \begin{tabular}{|l|}
80 \\
\end{tabular} & -1 & 100 & $\begin{array}{ll}0 \\
0\end{array}$ & 120 & +1 \\
\hline 2 & Час витримки & $\mathrm{XB}$ & $\tau$ & $x_{2}$ & 10 & 10 & -1 & 20 & 0 & 30 & +1 \\
\hline 3 & $\begin{array}{c}\text { Напруженість електро- } \\
\text { магнітного поля }\end{array}$ & $\mathrm{B} / \mathrm{cm}$ & $E$ & $x_{3}$ & 370,5 & 1852 & -1 & 2222,5 & 0 & 2593 & +1 \\
\hline
\end{tabular}

Табл. 2. Результати експериментальних досліджень

\begin{tabular}{|c|c|c|c|c|c|c|c|c|c|}
\hline \multirow{2}{*}{$№$ 3/п } & \multicolumn{3}{|c|}{ Кодоване позначення } & \multicolumn{3}{c|}{ Натуральне позначення } & \multicolumn{3}{c|}{ Результати досліджень } \\
\cline { 2 - 9 } & $x_{1}$ & $x_{2}$ & $x_{3}$ & $P$ & $\tau$ & $E$ & $y_{1}$ & $y_{2}$ & $y_{3}$ \\
\hline 1 & -1 & -1 & -1 & 80 & 10 & 1852 & 96,7 & 96,7 & 96,7 \\
\hline 2 & +1 & -1 & -1 & 120 & 10 & 1852 & 100 & 96,7 & 96,7 \\
\hline 3 & -1 & +1 & -1 & 80 & 30 & 1852 & 96,7 & 96,7 & 100 \\
\hline 4 & +1 & +1 & -1 & 120 & 30 & 1852 & 96,7 & 96,7 & 100 \\
\hline 5 & -1 & -1 & +1 & 80 & 10 & 2593 & 93,4 & 96,7 & 96,7 \\
\hline 6 & +1 & -1 & +1 & 120 & 10 & 2593 & 96,7 & 96,7 & 96,7 \\
\hline 7 & -1 & +1 & +1 & 80 & 30 & 2593 & 96,7 & 93,4 & 96,7 \\
\hline 8 & +1 & +1 & +1 & 120 & 30 & 2593 & 93,4 & 96,7 & 96,7 \\
\hline 9 & -1 & 0 & 0 & 80 & 20 & 2222,5 & 96,7 & 96,7 & 100 \\
\hline 10 & +1 & 0 & 0 & 120 & 20 & 2222,5 & 100 & 96,7 & 96,7 \\
\hline 11 & 0 & -1 & 0 & 100 & 10 & 2222,5 & 93,4 & 96,7 & 96,7 \\
\hline 12 & 0 & +1 & 0 & 100 & 30 & 2222,5 & 96,7 & 96,7 & 96,7 \\
\hline 13 & 0 & 0 & -1 & 100 & 20 & 1852 & 96,7 & 100 & 96,7 \\
\hline 14 & 0 & 0 & +1 & 100 & 20 & 2593 & 93,4 & 96,7 & 96,7 \\
\hline
\end{tabular}

Примітка: $y_{1}, y_{2}, y_{3}$ - результати експериментальних досліджень кількості якісних заготовок, отриманих у процесі гнуття, відповідно у першому, другому і третьому дослідах.

Результати експериментальних досліджень кількості якісних заготовок, отриманих внаслідок їх гнуття з одночасним нагріванням у полі струмів високої частоти, зведено в табл. 2.

Після статистичного оброблення отриманих результатів експериментальних досліджень, отримали регресійну залежність частки якісних заготовок від режимних параметрів процесу гнуття: тиску пресування, тривалості пресування та напруженості електромагнітного поля - у кодованому (1) та натуральному (2) вимірах.

$$
\begin{gathered}
y=96,975+0,22 x_{1}+0,11 x_{2}-0,88 x_{3}+0,825 x_{1}^{2}- \\
-0,825 x_{2}^{2}-0,275 x_{3}^{2}-0,275 x_{1} x_{2}-0,275 x_{2} x_{3},
\end{gathered}
$$

де: $x_{1}, x_{2}, x_{3}-$ значення вхідних факторів у кодованому позначенні.

$$
\begin{gathered}
K=103,304-0,374 P+0,643 \tau+0,008 E+0,002 P^{2}- \\
-0,008 \tau^{2}-0,000002 E^{2}-0,001 P \tau-0,00007 E \tau,
\end{gathered}
$$

де: $K$ - частка якісних деталей, $\% ; P$ - тиск пресування,

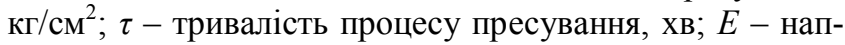
руженість електромагнітного поля, $\mathrm{B} / \mathrm{cm}$.

Суміщений графік експериментальних та теоретичних даних показано на рис. 6.

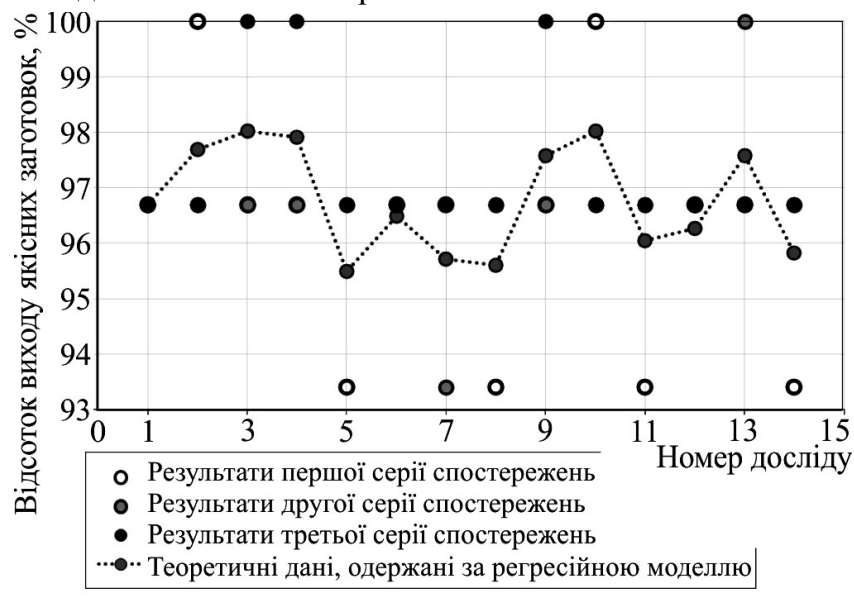

Рис. 6. Суміщений графік експериментальних та теоретичних даних, отриманих за регресійною залежністю
Для аналізу впливу режимних параметрів процесу гнуття деревини на вихід якісних гнутих заготовок доцільно побудувати три серії графічних залежностей (рис. 7-15).

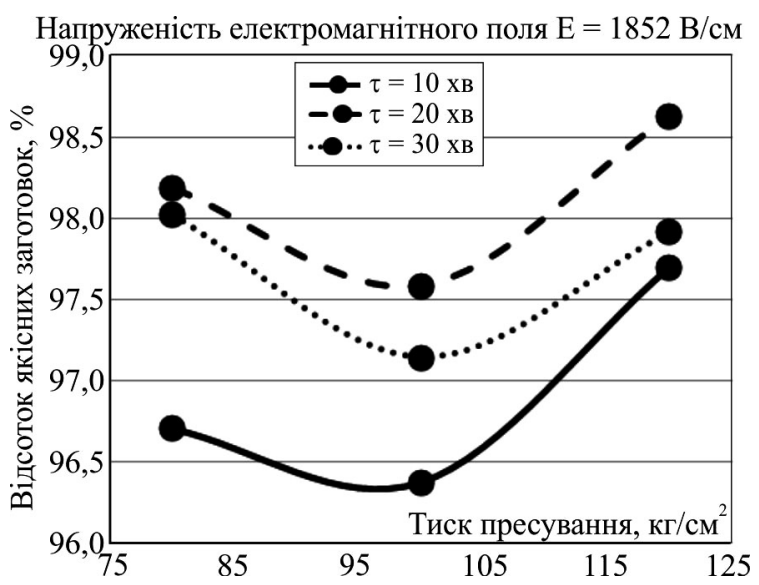

Рис. 7. Вплив тиску пресування та тривалості витримки на частку виходу якісних гнутих заготовок за сталої напруженості електромагнітного поля $E=1852 \mathrm{~B} / \mathrm{cm}$

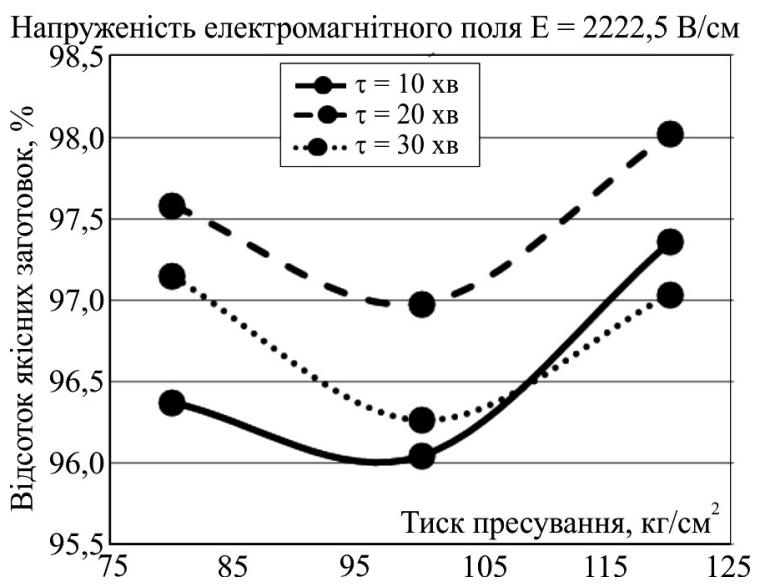

Рис. 8. Вплив тиску пресування та тривалості витримки на частку виходу якісних гнутих заготовок за сталої напруженості електромагнітного поля $E=2222,5 \mathrm{~B} / \mathrm{cm}$ 


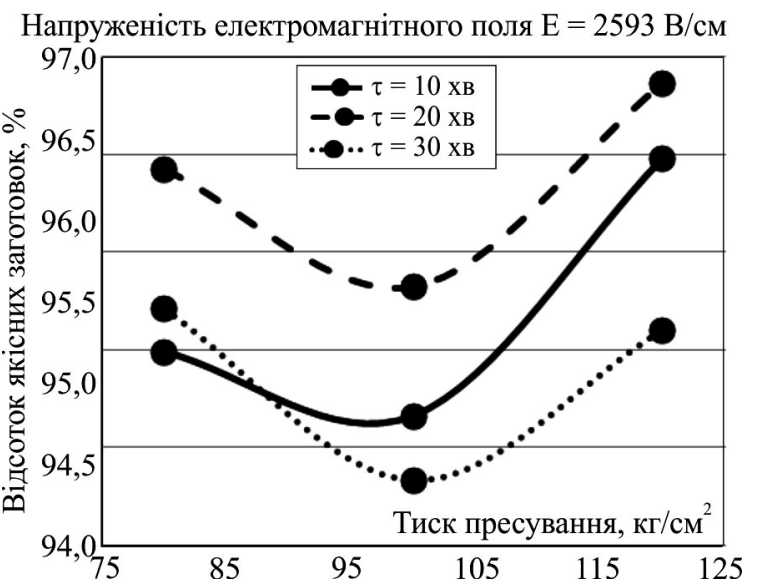

Рис. 9. Вплив тиску пресування та тривалості витримки на частку виходу якісних гнутих заготовок за сталої напруженості електромагнітного поля $E=2593 \mathrm{~B} / \mathrm{cm}$

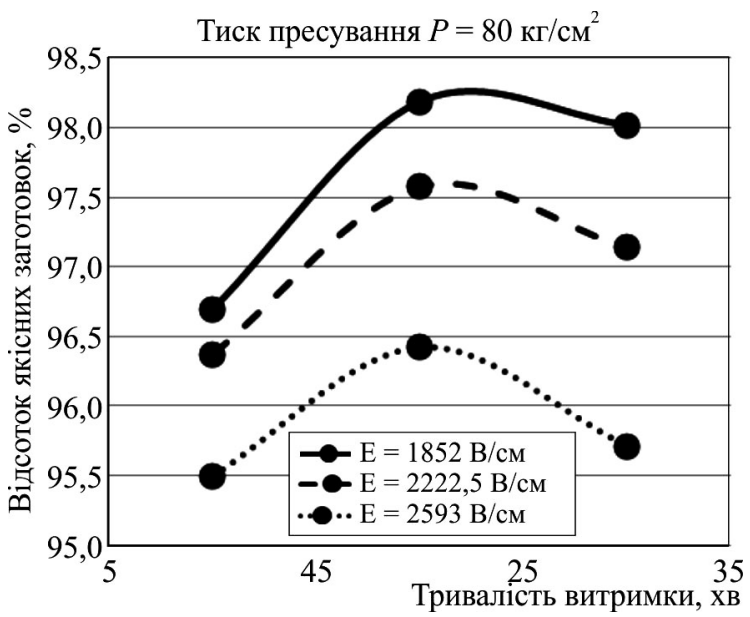

Рис. 10. Вплив тривалості пресування та напруженості електромагнітного поля на частку виходу якісних гнутих заготовок за сталого тиску пресування $P=80 \mathrm{\kappa} / \mathrm{cm}^{2}$

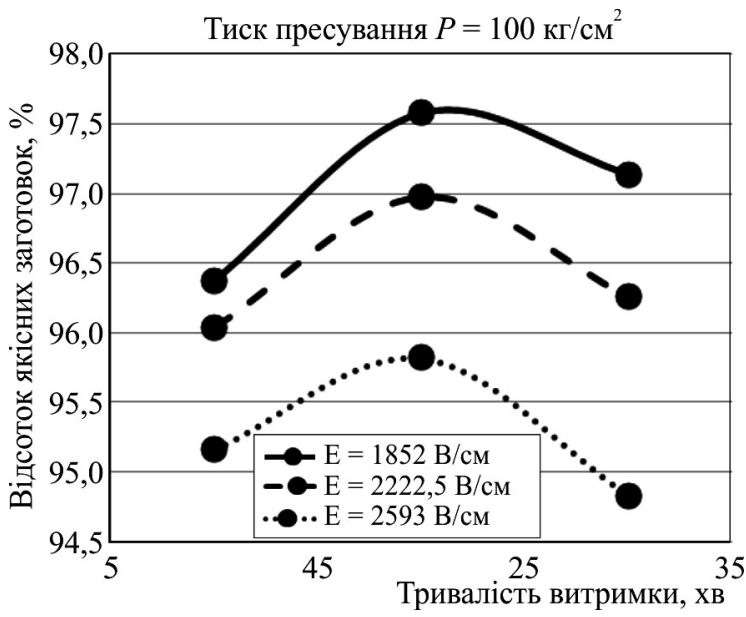

Рис. 11. Вплив тривалості пресування та напруженості електромагнітного поля на частку виходу якісних гнутих заготовок за сталого тиску пресування $P=100 \mathrm{\kappa} / \mathrm{cm}^{2}$

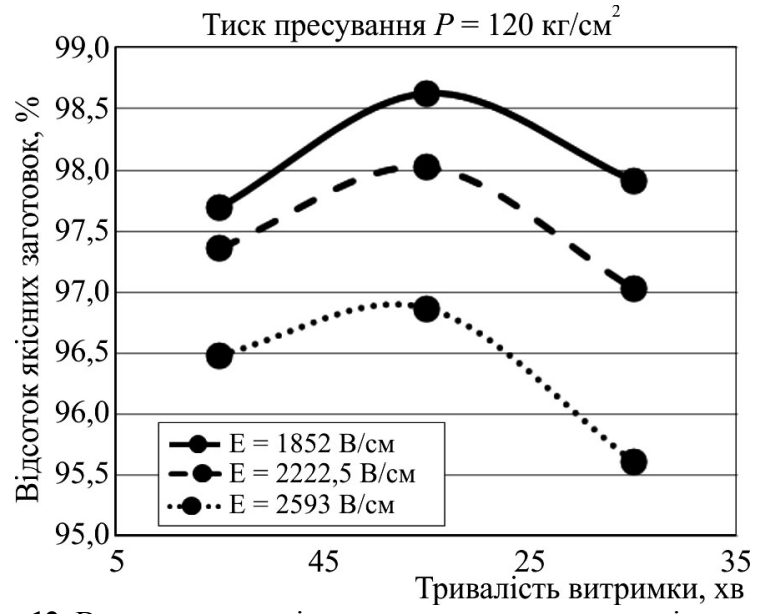

Рис. 12. Вплив тривалості пресування та напруженості електромагнітного поля на частку виходу якісних гнутих заготовок при сталому тиску пресування $P=120$ кг/ $\mathrm{cm}^{2}$

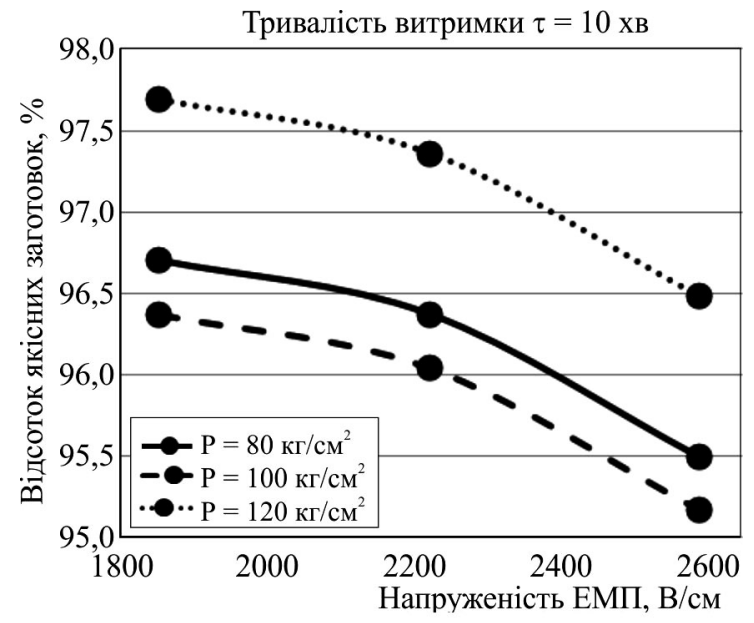

Рис. 13. Вплив напруженості електромагнітного поля та тиску пресування на частку виходу якісних гнутих заготовок за сталого тривалості пресування $\tau=10$ хв

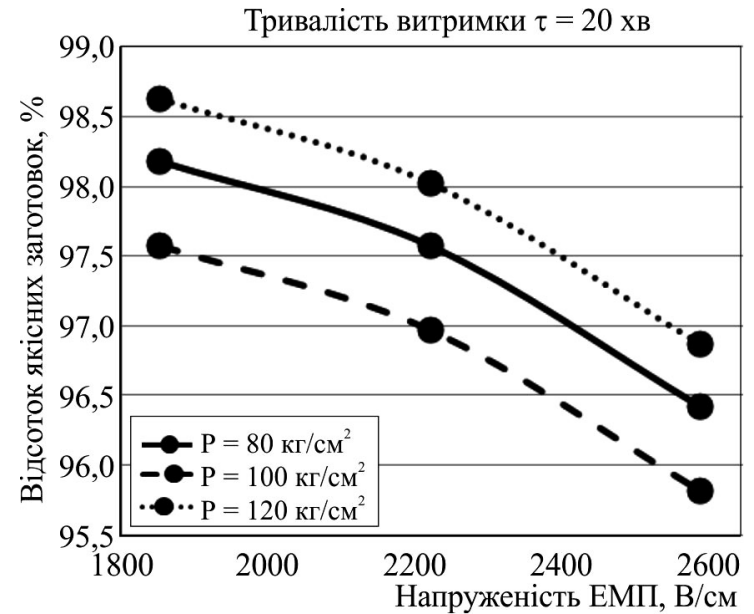

Рис. 14. Вплив напруженості електромагнітного поля та тиску пресування на частку виходу якісних гнутих заготовок за сталої тривалості пресування $\tau=20$ хв 


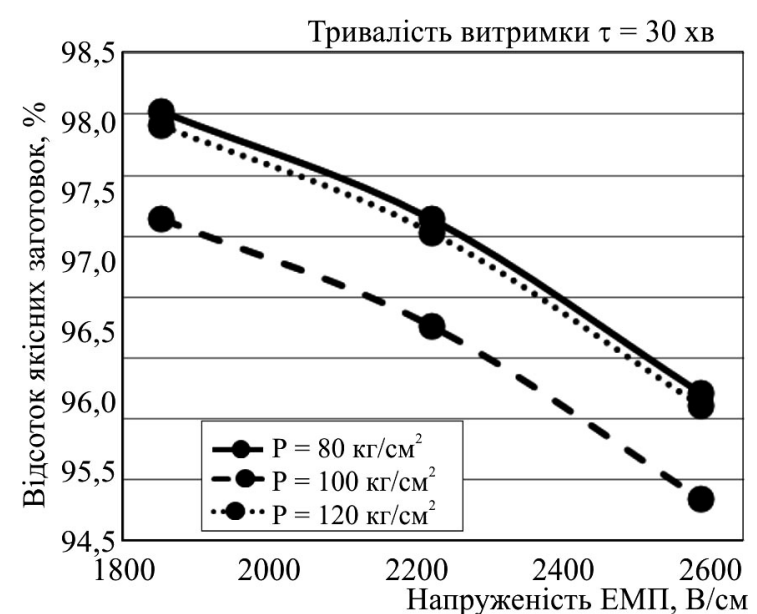

Рис. 15. Вплив напруженості електромагнітного поля та тиску пресування на частку виходу якісних гнутих заготовок за сталої тривалості пресування $\tau=30$ хв

Висновки. На основі аналізу отриманих графічних залежностей можна зробити такі висновки:

- збільшення тиску пресування до межі 100 кг/см² призводить до зменшення частки якісних гнутих заготовок, а за тиску $120 \mathrm{\kappa r} / \mathrm{cm}^{2}$ - якість зростає і $€$ більшою, ніж за 80 кг $/ \mathrm{cm}^{2}$

- збільшення часу витримки до межі 20 хв призводить до зростання частки якісних гнутих заготовок, а за межі 30 хв - до їх зменшення;

- із зростанням напруженості електромагнітного поля якість деталей погіршується.

За результатами оптимізації, найбільша частка якісних гнутих заготовок $(98,63 \%)$ можна отримати за найменшої напруженості електромагнітного поля $(E=$ 1852 B/см), за найбільшого значення тиску пресування $\left(P=120\right.$ кг $\left./ \mathrm{cm}^{2}\right)$ і тривалості пресування $\tau=20$ хв $40 \mathrm{c.}$

\section{Перелік використаних джерел}

Bilei, P. V. (Ed.). (2013). Teplomasoobminni protsesy derevoobrobky. Lviv: ZUKTs, 376 p. [In Ukrainian].

Goncharov, N. A., Bashinskikh, V. Iu., \& Buglai, B. M. (1990). Tekhnologiia izdelii iz drevesiny. (2nd ed.). Moscow: Lesn. promst, 528 p. [In Russian].

GOST 16588-91 (ISO 4470-81). (2009). Piloproduktciia i dereviannye detali. Metody opredeleniia vlazhnosti. Moscow: Standartinform. [In Russian].

Ozarkov, I. M., Soroka, L. Ya., \& Gryciuk, Yu. I. (1997). Fundamentals of aerodynamics and heat-mass exchange: manual. Kyiv: IZMN Publishing, 280 p. [In Ukrainian].

Yu. M. Huber, I. V. Petryshak, Zh. Ya. Humeniuk, M. M. Ilkiv Ukrainian National Forestry University, Lviv, Ukraine

\section{STUDYING THE PROCESS OF BEECH WOOD BENDING IN THE HIGH FREQUENCY HOT PRESS MACHINE}

The use of press machine equipped with microwave generators is the promising technology for manufacturing bent wood components. Heating of wood by high frequency currents allows heating it quickly to the desired temperature, in which wood plasticity will be the best. The time for the complete cycle of bending ranges from 20 to 40 minutes, the pressure is up to $500 \mathrm{~kg} / \mathrm{cm}^{2}$, the final moisture content of the workpieces varies from 6 to 8 percent. This technology significantly reduces time for wood bending and increases productivity compared to other equipment and technologies. The authors have presented the methodology and results of the research of the process of beech wood bending in high frequency hot press machines, as well as the influence of technological parameters directly on the quality of processed workpieces. The research was carried out under production conditions using the press machine of Italian company Italpress, with a total capacity of $35 \mathrm{~kW}$. Experiments were carried out on a template for bending with a $70 \mathrm{~mm}$ bending arrow using $975 \mathrm{~mm}$ long and $37 \times 27 \mathrm{~mm}$ cross-section workpieces. When analyzing the quality of bending, we have determined the number of suitable workpieces. We consider a workpiece to be of poor quality if it is not suitable due to its cracks, chips, dents, darkening and other defects, which make it impossible to use it from aesthetic or physical and mechanical requirements in furniture manufacture. According to the results of the research, we have obtained three groups of graphs for the dependence of the percentage of getting quality workpieces on the time of exposure, the electromagnetic field strength, and the amount of pressure when pressing. Therefore, we have made the following conclusions on the basis of the analysis of the obtained graphic dependencies. Firstly, an increase in the pressing pressure up to the limit of $100 \mathrm{~kg} / \mathrm{cm}^{2}$ leads to a decrease in the percentage of high quality workpieces, and at a pressure of $120 \mathrm{~kg} / \mathrm{cm}^{2}$, the percentage of high quality workpieces increases and is larger than $80 \mathrm{~kg} / \mathrm{cm}^{2}$. Secondly, increasing the time of exposure to 20 minute limit leads to an increase in the percentage of high quality workpieces, and beyond 30 minute limit causes reduction of the percentage of high quality workpieces. Finally, as the intensity of the electromagnetic field increases, the percentage of high quality workpices decreases. In order to find optimal parameters of beech wood worpieces bending, we have done an optimization. According to this optimization we can argue that the greatest number of high quality bent workpieces $(98.63 \%)$ can be obtained at the lowest voltage of the electromagnetic field and at the greatest pressure value of compression, and the workpieces exposure under pressure for 20 minutes and 40 seconds as well.

Keywords: beech wood workpiece; process of bending; time for exposure; electromagnetic field strength; pressing pressure. 